Review

\title{
The CLV-WUS Stem Cell Signaling Pathway: A Roadmap to Crop Yield Optimization
}

\author{
Jennifer C. Fletcher 1,2 (iD) \\ 1 Plant Gene Expression Center, United States Department of Agriculture-Agricultural Research Service, \\ Albany, CA 94710, USA; jfletcher@berkeley.edu; Tel.: +1-510-559-5917; Fax: +1-510-559-5678 \\ 2 Department of Plant and Microbial Biology, University of California, Berkeley, CA 94720, USA
}

Received: 12 September 2018; Accepted: 10 October 2018; Published: 19 October 2018

\begin{abstract}
The shoot apical meristem at the growing shoot tip acts a stem cell reservoir that provides cells to generate the entire above-ground architecture of higher plants. Many agronomic plant yield traits such as tiller number, flower number, fruit number, and kernel row number are therefore defined by the activity of the shoot apical meristem and its derivatives, the floral meristems. Studies in the model plant Arabidopsis thaliana demonstrated that a molecular negative feedback loop called the CLAVATA (CLV)-WUSCHEL (WUS) pathway regulates stem cell maintenance in shoot and floral meristems. CLV-WUS pathway components are associated with quantitative trait loci (QTL) for yield traits in crop plants such as oilseed, tomato, rice, and maize, and may have played a role in crop domestication. The conservation of these pathway components across the plant kingdom provides an opportunity to use cutting edge techniques such as genome editing to enhance yield traits in a wide variety of agricultural plant species.
\end{abstract}

Keywords: CLE; CLV; WUS; stem cells; meristem; SAM; signaling; locule

\section{Introduction}

Plants are unique among living organisms in their ability to continuously grow and develop new organs throughout their life cycles. This continuous growth strategy produces leaves, stems, and flowers in architectures that can vary widely between species, from squat yellow dandelions to tall, leafy trees. The sources of cells for continuous organ formation are the apical meristems at the growing shoot and root tips. The shoot apical meristem (SAM) forms in the embryo and consists of a small reservoir of stem cells whose descendants generate all of the above-ground structures of the plant [1]. Following germination, the vegetative SAM produces a series of leaves from its flanks. At the transition to flowering the vegetative meristem becomes a reproductive inflorescence meristem (IFM) that produces axillary meristems followed by floral meristems that generate the flowers and seeds. Thus, SAM activity is the ultimate source of many yield traits in agronomic crop plants, because the direct outcome of plant organogenesis is the production of leaves, fruits, pods, seeds, and other structures that humans harvest and eat.

The SAM has the dual function of maintaining an active stem cell population while concurrently generating new organs. The organs form as primordia on the meristem flanks, while the self-renewing stem cell reservoir at the apex replenishes the cells that depart from the meristem into the primordia (Figure 1A). The stem cell pool is sustained by the activity of an underlying group of cells in the core of the SAM called the organizing center (OC). The maintenance of SAM homeostasis via a balance between stem cell loss and renewal is critical for plant development, because plants with reduced SAM activity prematurely cease growth before forming their full complement of organs $[2,3]$ whereas those with over-active meristems have enlarged stems and can produce many extra branches, flowers, fruits, and seeds $[4,5]$. 


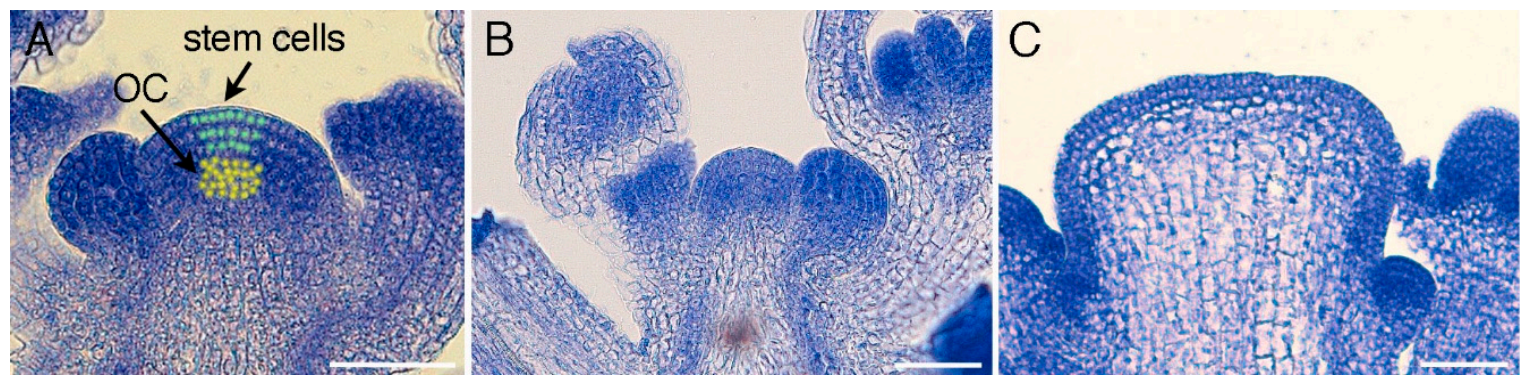

Figure 1. Shoot apical meristems of Arabidopsis wild-type and clv3 mutant plants during the inflorescence phase. (A) Key domains within the shoot apical meristem. The apical stem cells are colored in green and the underlying organizing center (OC) cells in yellow. Primordia arise as dome-shaped structures on the meristem flanks. (B) Wild-type Columbia-0 inflorescence meristem (IFM) and flanking floral meristem primordia. (C) Enlarged clv3 null mutant IFM and flanking floral meristem primordia. Scale bars, $50 \mu \mathrm{m}$.

Communication between individual cells is crucial to coordinate the various aspects of SAM function. Classical experiments demonstrated that the fate of each SAM cell is determined by positional information rather than by its lineage-specific heritage [6-8], and that the distinct functional domains within the SAM exchange cell fate information cues [9]. The SAM is further stratified into clonally distinct cell layers [10-12] that participate in both SAM maintenance and organ formation [13,14], requiring that these activities be orchestrated between all cell layers. Therefore, signaling between SAM cells is necessary for the cells to assess their relative positions in the meristem and behave coordinately with their neighbors. As described below, a molecular network called the CLAVATA (CLV)-WUSCHEL (WUS) pathway conveys intercellular signals that are critical for shoot and floral meristem maintenance in higher plants.

Crop plants have undergone vigorous selection by humans during the past 10,000 years [15,16], especially for yield traits such as larger and more numerous inflorescence meristems, fruits, and seeds. The CLV-WUS pathway in particular has been a target of selection during crop domestication to enhance agricultural yields [17]. Here, I review our understanding of the CLV-WUS signaling system in Arabidopsis shoot meristems and discuss studies demonstrating that components of the pathway are associated with variation in yield traits in agronomic crops such as mustard, tomato, rice, and maize.

\section{CLV-WUS Shoot Apical Meristem Maintenance Pathway}

The CLV-WUS signaling pathway plays a central role in maintaining shoot and floral stem cell homeostasis in Arabidopsis (Figure 2A). The WUS gene is dispensable for establishing the embryo stem cell reservoir [18], but is required to sustain stem cell fate during vegetative and reproductive development [3]. WUS is expressed exclusively in the SAM organizing center and encodes a homeodomain transcription factor of the WUSCHEL-LIKE HOMEOBOX (WOX) family [19]. WUS is a bi-functional protein that can both repress and activate gene transcription in the SAM [20]. Among the key targets of direct WUS repression in the OC are negative regulators of cytokinin activity, a hormone that promotes cell proliferation across the SAM [21]. WUS also directly represses the transcription of cell differentiation-inducing transcription factor genes that are normally expressed in organ primordia, to prevent premature stem cell differentiation at the apex of the SAM [22]. In addition, WUS protein moves between cells through plasmodesmata into the apical stem cell domain [23] where it maintains stem cell fate and induces the expression of the CLV3 gene in a dosage-dependent fashion [24,25]. WUS functions together with members of the HAIRY MERISTEM (HAM) family of GRAS domain transcriptional regulators to regulate stem cell production [26] and to ensure that CLV3 transcription is activated exclusively in the outermost apical layers of the SAM [27]. 


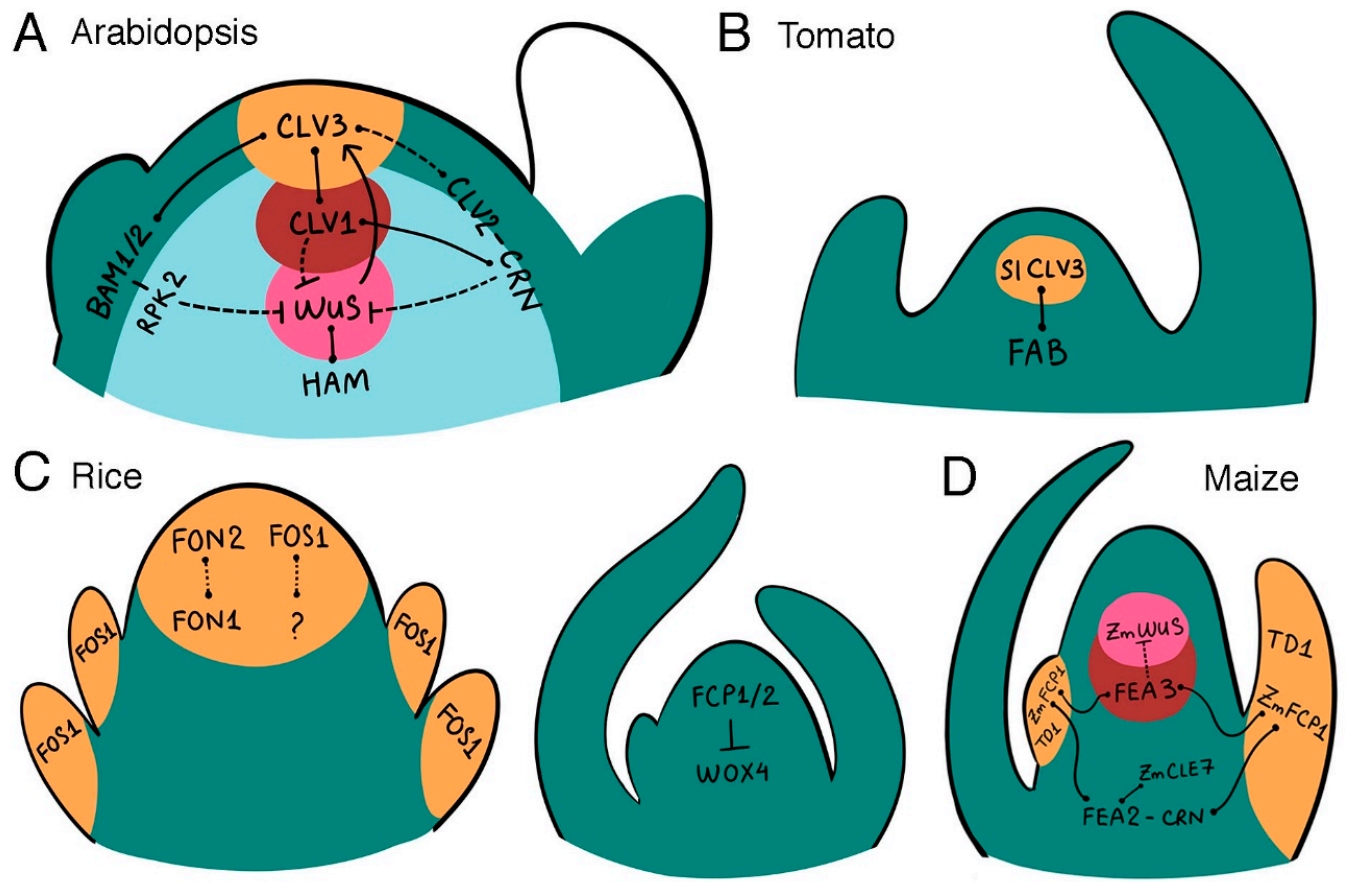

Figure 2. CLV-WUS signaling pathways in model and crop plant meristems. (A) Arabidopsis SAM. (B) Tomato SAM. (C) Rice FM and SAM. (D) Maize SAM. Genes with characterized genetic and/or biochemical interactions are shown. Arrows depict positive regulation and bars depict negative regulation. Solid lines represent direct interactions and dashed lines represent indirect interactions. Solid lines with rounded ends depict direct peptide-receptor interactions. Unidentified receptors for peptides are denoted by question marks.

The CLV signal transduction pathway negatively regulates stem cell accumulation in above-ground meristems. Mutations in Arabidopsis CLV genes cause progressive enlargement of the shoot and floral stem cell pools (Figure 1B,C), resulting in plants with enlarged stems and excess flowers, as well as flowers with extra sepals, petals and stamens, and siliques with more than two locules $[4,28]$. CLV3 encodes a founding member of the CLAVATA3/EMBRYO SURROUNDING REGION (CLE) family of polypeptides [29], which are present throughout the plant kingdom [30,31]. CLV3 is expressed within the shoot and floral stem cell domain [32] and encodes a pre-propeptide that is processed into a $12-13$ amino acid arabinosylated glycoprotein [33,34]. This glycoprotein moves through the extracellular space to communicate stem cell fate information with neighboring cells [35].

The CLV3 signal is perceived and transduced at the plasma membrane by several distinct sets of receptors (Figures 2A and 3). CLV3 peptides are bound by the CLV1 leucine-rich repeat receptor-like kinase (LRR-RLK) that is produced in cells beneath the stem cell reservoir [36,37]. A second distinct receptor complex consists of heterodimers of the CLV2 LRR receptor-like protein [38] and the CORYNE (CRN) protein, a presumptive pseudokinase that functions as a CLV2 co-receptor [39,40]. CRN mediates localization of CLV2/CRN complexes to the plasma membrane [41], where they can directly interact with CLV1 heterodimers [41-43]. Yet in contrast to CLV1, CLV2 and CRN are expressed throughout the entire SAM, and the CLV2-CRN complex functions largely independently of CLV1 in CLV3 signal transduction $[39,41,43]$. Reports differ as to whether the CLV2 receptor itself directly binds the CLV3 ligand or if an additional co-receptor is required [42,44]. Other receptors appear to mediate CLV3 signaling predominantly on the flanks of the meristem. Three LRR-RLK genes that form a monophyletic group with CLV1, termed BARELY ANY MERISTEM1, 2 and 3 (BAM1-3), act redundantly to promote stem cell maintenance on the meristem periphery [45], and both BAM1 and BAM2 directly bind CLV3 peptides [42,44]. The BAM1 protein physically associates with the LRR receptor-like kinase RECEPTOR-LIKE PROTEIN KINASE2 (RPK2) [46], which itself does not 
bind CLV3 peptides and thus is proposed to regulate meristem maintenance by transmitting the CLV3 signal through the BAM1 pathway [44]. An additional group of four LRR-RLKs termed the CLAVATA3 INSENSITIVE RECEPTOR KINASES (CIKs) undergo rapid phosphorylation in response to CLV3 signaling, and appear to function as co-receptors for the CLV1, CLV2-CRN, and BAM-RPK2 receptor pathways [47]. CLV3-mediated signaling through these receptor complexes limits stem cell accumulation by restricting the WUS expression domain to the OC $[48,49]$. Thus, the CLV-WUS pathway functions as a dynamic negative feedback loop that allows the stem cell domain and the underlying OC to continually adjust their size relative to one another to maintain SAM homeostasis.

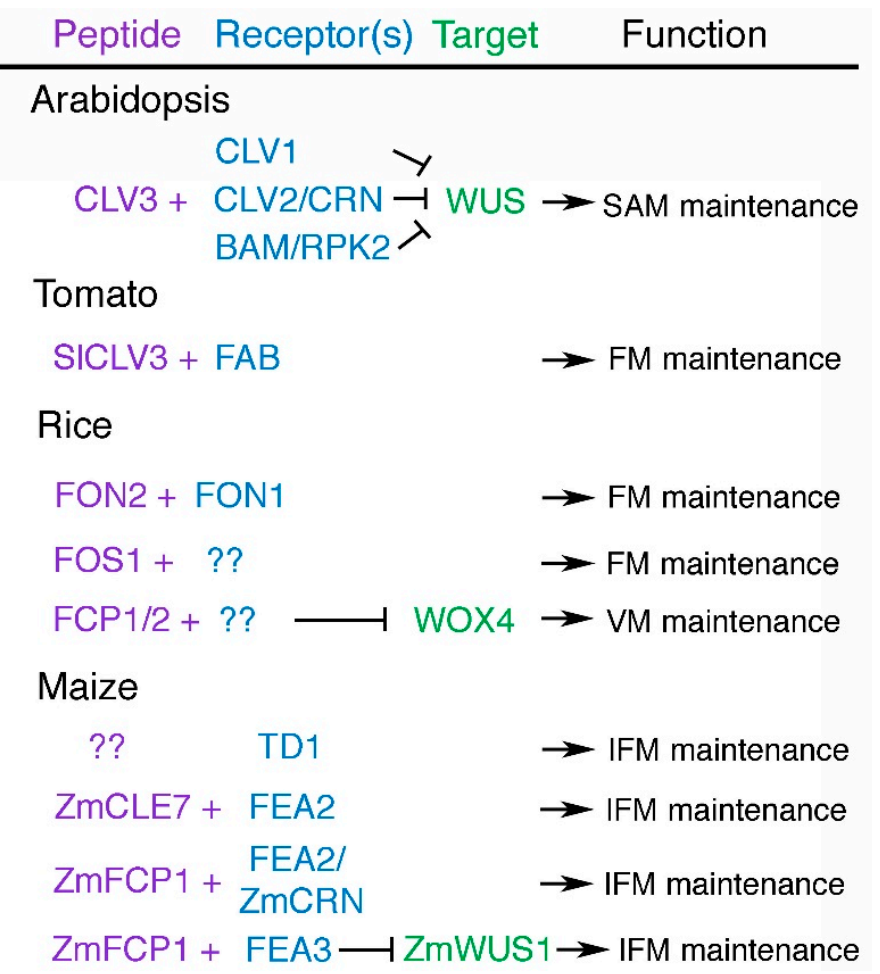

Figure 3. Components of CLV-WUS signaling pathways and their functions in model and crop plants. Proteins with characterized genetic and/or biochemical interactions are listed. Unidentified peptides and receptors are denoted by question marks. Arrows depict positive regulation and bars depict negative regulation. SAM, shoot apical meristem; FM, floral meristem; VM, vegetative meristem; IFM, inflorescence meristem.

\section{CLV-WUS Pathway in Dicotyledonous Crop Plants}

Arabidopsis thaliana is related to cultivated mustard varieties-such as Brassica rapa, Brassica juncea, and Brassica napus - which are agriculturally important oil crops that provide edible oils for human diets as well as raw material for animal feed and industrial processes such as biodiesel production [50]. Like Arabidopsis, oilseed floral meristems produce sepals, petals, stamens, and two carpels, the latter of which develop into the two locules of the siliques. The oil and protein products of Brassica plants are contained inside the seeds that develop within the siliques, and thus enhancing silique yield traits has long been a major goal of oilseed production and genetic improvement [51,52].

Several multilocular Brassica lines with more than two locules have been identified in natural populations [53], and recent studies have implicated CLV-WUS pathway components in the appearance of this trait (Table 1). The B. rapa var. yellow sarson ml4 mutant exhibits a multilocular phenotype caused by a single nucleotide mutation in a CLV3 gene homolog that produces an amino acid substitution in the CLE domain [54]. Similarly, a multilocular phenotype found in the B. juncea Duoshi cultivar results from mutations in a CLV1 gene homolog, $B j \operatorname{Ln} 1[55,56]$, while a trilocular phenotype in $B$. juncea J163-4 plants is caused by the insertion of a copia-LTR retrotransposable element into the coding 
region of a second CLV1 homolog, BjMc1, interrupting its transcription [52]. These multilocular Brassica plants have significantly higher yield than the corresponding bilocular plants without affecting viability [54,56,57], suggesting that selectively targeting $C L V$ genes can be a powerful method of obtaining high-yield oilseed cultivars. This has been tested by the use of CRISPR-Cas9 genome editing to target $C L V$ pathway components in allotetraploid B. napus plants, which contain two copies each of the CLV1, CLV2, and CLV3 genes [50]. Simultaneous mutation of both copies of any of the three $B n C L V$ genes resulted in plants with enlarged IFMs, multilocular siliques, and higher seed yield, with mutations in the BnCLV3 genes producing the most severe effects [50].

Table 1. $C L V$ peptide and receptor gene orthologs in crop plants

\begin{tabular}{cccccc}
\hline Gene Ortholog & \multicolumn{5}{c}{} \\
\hline Arabidopsis & Brassica & Tomato & Rice & Maize & References \\
CLV3 & BrCLV3 & SICLV3 & FON2 & ZmCLE7 & {$[32,54,58-61]$} \\
CLV1 & BjMc1; BjLn1 & FAB & FON1 & TD1 & {$[36,52,56,62,63]$} \\
CLV2 & BnA02CLV2; BnC02CLV2 & $?$ & $?$ & FEA2 & {$[5,38,50]$} \\
CRN & $?$ & $?$ & $?$ & ZmCRN & {$[39,61]$} \\
\hline
\end{tabular}

Members of the CLV-WUS pathway also play key roles in regulating locule number in tomato (Table 1, Figure 2B). The wild ancestor of tomato had a small, bilocular fruit, whereas modern tomato varieties contain eight or more locules [64]. The fasciated (fas) and locule number (lc) genes are the major quantitative trait loci (QTL) controlling the number of tomato fruit locules, and most cultivated tomato varieties contain mutations in either the fas or the fas and $l c$ genes [65]. The multilocular fas phenotype results from a mutation in the regulatory region of a CLV3-related gene, SlCLV3 [59], whereas the lc trait is caused by two single nucleotide polymorphisms (SNPs) in a repressor element downstream of a WUS gene homolog [66,67]. Evidence suggests that selection at both loci took place during tomato domestication to produce plants with increased fruit locule number [59,66]. Generation of a suite of novel SICLV3 promoter alleles using genome editing produced plants with a continuum of variation in fruit locule number [67], providing a blueprint for engineering quantitative variation in yield traits for breeding purposes.

In addition, a forward genetic screen for tomato mutants with increased inflorescence branching and fruit locule number identified both known and novel CLV pathway members [59]. Plants with the fasciated and branched (fab) multilocular phenotype contain a missense mutation in the closest tomato homolog of CLV1, which affects the kinase domain. Interestingly, the fasciated inflorescence (fin) and fab2 phenotypes are caused by mutations in arabinosyltransferase genes. Arabinosyltransferases catalyze the transfer of L-arabinose to the hydroxyl group of hydroxyproline (Hyp) residues in their target proteins [68]. In Arabidopsis, the Hyp ${ }^{7}$ residue of the active CLV3 polypeptide is post-translationally modified with three L-arabinose residues [34,69], and the addition of arabinosylated SICLV3 peptides can rescue the tomato fin phenotype [59]. Therefore, arabinosyltransferase genes are critical components of the CLV-WUS stem cell signaling pathway that can impact crop productivity traits.

\section{CLV-WUS Pathway in Grasses}

The broad function of the CLV-WUS pathway in mediating shoot meristem maintenance is conserved in agronomically important grass species (Table 1, Figure 2C), with some important modifications. In rice (Oryza sativa L.), stem cell maintenance appears to be regulated by several distinct pathways, the relative contributions of which depend on the type of meristem. The FLORAL ORGAN NUMBER (FON1) and FON2 genes restrict stem cell accumulation specifically in floral meristems, without affecting vegetative or inflorescence meristem activity [70]. FON1 encodes the rice ortholog of the CLV1 receptor kinase [62]. It is expressed within the floral meristems but also within the shoot meristem throughout development, suggesting that related receptor kinase genes share functional redundancy with FON1 in vegetative and inflorescence tissues [62]. Such genes, however, 
remain to be characterized. The FON2 gene, also referred to as FON4, functions in the same genetic pathway as FON1 and encodes a CLV3-related protein [58,60]. Like CLV3, FON2 is expressed at the apex of both shoot and floral meristems [58,60]. Thus, in rice floral meristems, the FON1-FON2 system corresponds to the CLV1-CLV3 peptide-receptor kinase signaling system in Arabidopsis (Figure 3).

Several other CLE genes also play roles in orchestrating rice meristem maintenance (Figures 2C and 3). QTL analysis identified the FON2 SPARE1 (FOS1) gene in indica varieties as a suppressor of the fon 2 floral organ number phenotype in japonica, indicating that FOS1 can substitute for FON2 activity in rice floral meristems [71]. Constitutive expression of FOS1 leads to termination of the vegetative SAM, suggesting a potential function for FOS1 in vegetative SAM cell maintenance [71]. The FOS1 CLE domain is more similar to Arabidopsis CLE8 and CLE13 than to CLV3, and because FOS1 activity does not require FON1, FOS1 signaling is thought to occur largely in parallel with the FON1-FON2 pathway [71]. Two other CLE genes, FON2-LIKE CLE PROTEIN1 (FCP1) and FCP2, encode proteins that differ in the CLE domain by one amino acid [72] and act redundantly to negatively regulate vegetative stem cell activity and promote leaf initiation [73]. FCP1 represses the expression of rice WOX4, an ortholog of Arabidopsis WOX4 [74], which promotes the undifferentiated state of the vegetative SAM [73]. Thus the rice WOX4 gene functions similarly to the Arabidopsis WUS gene [19], whereas the WUS ortholog in rice [74], called TILLERS ABSENT1 (TAB1), is required for axillary meristem initiation but not for shoot or floral meristem maintenance [75]. These studies identify additional CLE signaling peptide genes besides $C L V 3$ as potential targets for genome editing to enhance yield traits in crop plants, particularly grasses.

Maize is a monoecious plant that develops two distinct inflorescence meristem structures: the terminal IFM, called the tassel, that bears male flowers; and the axillary IFMs, called the ears, that bear female flowers. The ear inflorescence meristems produce multiple rows of secondary meristems called spikelet pair meristems, which branch to form spikelet meristems. The spikelet meristems then branch to form two floral meristems, one of which develops into a flower (and after fertilization, a seed kernel) while the other aborts. Modern cultivated corn varieties contain between 8 and 20 rows of kernels within their ears [76], compared to the two rows of kernels found in teosinte, the ancestor of maize, and the ability of the ear IFM to produce additional rows of spikelet meristems appears to have been a major factor in the maize domestication process $[5,15]$. Molecular evidence indicates that CLV-WUS pathway components underlie much of the variation in this key yield trait.

Mutations at multiple maize loci generate fasciated phenotypes in which the male and/or female inflorescences are enlarged and display increased numbers of spikelet pair and/or spikelet meristems [77]. One of the first such mutants cloned was thick tassel dwarf1 (td1), which displays increased tassel and ear IFM size and results from a mutation in the maize ortholog of the CLV1 gene [63] (Table 1). The TD1 locus maps near QTL for tassel spikelet density and for kernel row number [63], whereas the FASCIATED EAR2 (FEA2) gene encodes the maize ortholog of CLV2 [5] and corresponds to a distinct QTL for kernel row number [78]. Thus multiple CLV receptors are likely to have been targets of selection during maize domestication (Figures 2D and 3).

The FEA2 receptor-like protein is proposed to regulate meristem maintenance by transmitting signals from two different CLE peptides through two distinct downstream pathways. FEA2 physically associates in vivo with COMPACT PLANT2 (CT2), the alpha subunit of the heterotrimeric GTP binding protein [79] that along with other G $\alpha$ domain-containing eXtra Large GTP-binding proteins (XLGs) contribute to restricting IFM size [80]. In CLE peptide response assays both fea2 and ct2 plants are resistant to application of ZmCLE7, the maize CLV3 ortholog, suggesting that ZmCLE7 peptide signaling is transmitted across the plasma membrane by a FEA2-CT2 receptor-G protein complex [61]. FEA2 also heterodimerizes with ZmCRN, which acts in separate pathway from CT2. Zmcrn plants are sensitive to ZmCLE7 application, but both fea2 and Zmcrn plants are resistant to the application of a related CLE peptide ZmFCP1. In contrast to ZmCLE7, ZmFCP1 is not expressed in the SAM but is detected in incipient and initiating leaf primordia [81]. FEA2, therefore, also appears capable of transmitting a ZmFCP1 signal from organ primordia to regulate IFM activity through 
a ZmCRN-mediated pathway. Interestingly, the ZmCRN locus has significant association with kernel row number variability [82], suggesting that it too contributes to quantitative variation in this trait.

Finally, the CLE peptide ZmFCP1 signals through the LRR receptor-like protein FASCIATED EAR3 (FEA3) to suppress the expression of ZmWUS1 in the region below the organizing center [81] (Figure 2D). Computational models suggest that ZmFCP1 signaling from developing organ primordia is sufficient to restrict stem cell accumulation in the neighboring SAM by limiting the size of the ZmWUS1 expression domain [81]. Whether the other maize WUS ortholog, ZmWUS2, is also a target of ZmFCP1-FEA3 signaling is unknown. FEA3 acts in a separate pathway than FEA2 and weak alleles of FEA3 and FEA2 independently enhance kernel row number, although weak fea 2 alleles do not increase overall yield due to a compensatory reduction in kernel size $[78,81]$. Nonetheless, in maize as in other crop plants, the reduction of stem cell regulatory gene activity can lead to improvement of agronomic traits.

\section{Perspectives}

Gene homologies between Arabidopsis and agronomic plants continue to be robust tools for technology transfer, facilitating the translation of basic genetic and genomic information into direct crop improvements. A recent study of the moss Physcomitrella patens reveals that the core components of the CLV signaling pathway, namely a CLE peptide and a CLV1/BAM-like RLK, originated with land plants, and that their ability to regulate stem cell proliferation and cell fate is likely to be an ancestral feature of land plants that enabled three-dimensional growth [31]. To date, CLE genes have been identified in over 50 plant species, including Medicago truncatula, Lotus japonicas, wheat, potato, soybean, common bean, banana, and poplar [30]. Additionally, members of the WUS clade of WOX genes with stem cell-related functions appeared after the divergence of vascular plants from bryophytes [83]. Thus, the potential for modulating the CLV-WUS pathway and related CLE genes to enhance yield traits exists in a very large number of agricultural plant species.

To date, a major challenge to manipulating yield trait genes in agronomic plants has been the presence of multiple genes within the genome that encode redundant or overlapping stem cell maintenance functions. For example, several homologous copies of the CLV1, CLV2, and CLV3 genes exist within polyploid genomes such as Brassica napa [50] and wheat (Triticum aestivum L.) [84]. In addition, genetic evidence indicates that multiple CLE genes as well as multiple CLV1/BAM LRR-RLK gene paralogs are involved in the regulation of stem cell maintenance. The advent of multiplex genome editing, which directs the simultaneous targeting of multiple members of a gene family as well as multiple components of a molecular pathway [85], offers great potential to produce beneficial architecture modifications in both dicot and monocot crop species. In this respect, it is worth noting that hypomorphic mutations that reduce CLV-WUS gene function, such as mutations in tomato CLV3 or WUS regulatory regions $[59,66,67]$ or missense mutations in maize CLV1 or CLV2 receptor kinase genes $[78,81]$, can be sufficient to achieve significant yield increases without the need to completely eliminate gene function. Thus, novel approaches such as genome editing of stem cell maintenance gene promoters [67] may also be a fruitful approach to fine-tune CLV-WUS signaling and thus tailor yield trait optimization within individual crop species.

Author Contributions: The author is responsible for all aspects of the manuscript.

Funding: This research was funded by the United States Department of Agriculture CRIS grant number 2030-21000-048-00D.

Acknowledgments: The author thanks Thai Q. Dao for the illustrations used in Figure 2, and Dezhi Du, Thai Q. Dao and Wassim Hage for helpful comments.

Conflicts of Interest: The author declares no conflict of interest. The funding sponsors had no role in the design of the study; in the collection, analyses, or interpretation of data; in the writing of the manuscript, or in the decision to publish the results. 


\section{References}

1. Steeves, T.A.; Sussex, I.M. Patterns in Plant Development; Cambridge University Press: New York, NY, USA, 1989.

2. Kieffer, M.; Stern, Y.; Cook, H.; Clerici, E.; Maulbetsch, C.; Laux, T.; Davies, B. Analysis of the transcription factor WUSCHEL and its functional homologue in Antirrhinum reveals a potential mechanism for their roles in meristem maintenance. Plant Cell 2006, 18, 560-573. [CrossRef] [PubMed]

3. Laux, T.; Mayer, K.F.X.; Berger, J.; Jurgens, G. The WUSCHEL gene is required for shoot and floral meristem integrity in Arabidopsis. Development 1996, 122, 87-96. [PubMed]

4. Clark, S.E.; Running, M.P.; Meyerowitz, E.M. CLAVATA1, a regulator of meristem and flower development in Arabidopsis. Development 1993, 119, 397-418. [PubMed]

5. Taguchi-Shiobara, F.; Yuan, Z.; Hake, S.; Jackson, D. The FASCIATED EAR2 gene encodes a leucine-rich repeat receptor-like protein that regulates shoot meristem proliferation in maize. Genes Dev. 2001, 15, 2755-2766. [CrossRef] [PubMed]

6. Furner, I.J.; Pumfrey, J.E. Cell fate in the shoot apical meristem of Arabidopsis thaliana. Development 1992, $115,755-764$.

7. Irish, V.F.; Sussex, I.M. A fate map of the Arabidopsis embryonic shoot apical meristem. Development 1992, $115,745-753$.

8. Poethig, R.S.; Coe, E.H.J.; Johri, M.M. Cell lineage patterns in maize Zea mays embryogenesis: A clonal analysis. Dev. Biol. 1986, 117, 392-404. [CrossRef]

9. Sussex, I.M. Experiments on the cause of dorsiventrality in leaves. Nature 1954, 174, 351-352. [CrossRef]

10. Poethig, R.S. Clonal analysis of cell lineage patterns in plant development. Am. J. Bot. 1987, 74, 581-594. [CrossRef]

11. Satina, S.; Blakeslee, A.F.; Avery, A.G. Demonstration of the three germ layers in the shoot apex of Datura by means of induced polyploidy in periclinal chimeras. Am. J. Bot. 1940, 27, 895-905. [CrossRef]

12. Tilney-Bassett, R.A.E. Plant Chimeras; E. Arnold: London, UK, 1986.

13. Poethig, R.S.; Sussex, I.M. The cellular parameters of leaf development in tobacco: A clonal analysis. Planta 1985, 165, 170-184. [CrossRef] [PubMed]

14. Poethig, R.S.; Sussex, I.M. The developmental morphology and growth dynamics of the tobacco leaf. Planta 1985, 165, 158-169. [CrossRef] [PubMed]

15. Doebley, J.F.; Gaut, B.A.; Smith, B.D. The molecular genetics of crop domestication. Cell 2006, 127, $1309-1321$. [CrossRef] [PubMed]

16. Kuittinen, H.; Aguade, M. Nucleotide variation at the CHALCONE ISOMERASE locus in Arabidopsis thaliana. Genetics 2000, 155, 863-872. [PubMed]

17. Somssich, M.; Je, B.I.; Simon, R.; Jackson, D. CLAVATA-WUSCHEL signalling in the shoot meristem. Development 2016, 143, 3238-3248. [CrossRef] [PubMed]

18. Zhang, Z.; Tucker, E.; Hermann, M.; Laux, T. A molecular framework for the embryonic initiation of shoot meristem stem cells. Dev. Cell 2017, 40, 264-277. [CrossRef] [PubMed]

19. Mayer, K.F.X.; Schoof, H.; Haecker, A.; Lenhard, M.; Jurgens, G.; Laux, T. Role of WUSCHEL in regulating stem cell fate in the Arabidopsis shoot meristem. Cell 1998, 95, 805-815. [CrossRef]

20. Ikeda, M.; Mitsuda, N.; Ohme-Takagi, M. Arabidopsis WUSCHEL is a bifunctional transcription factor that acts as a repressor in stem cell regulation and as an activator in floral patterning. Plant Cell 2009, 21, 3493-3505. [CrossRef] [PubMed]

21. Leibfried, A.; To, J.P.C.; Busch, W.; Stehling, S.; Kehle, A.; Demar, M.; Kieber, J.J.; Lohmann, J.U. WUSCHEL controls meristem function by direct regulation of cytokinin-inducible response regulators. Nature 2005, 438, 1172-1175. [CrossRef] [PubMed]

22. Yadav, R.K.; Perales, M.; Gruel, J.; Ohno, C.; Heisler, M.; Girke, T.; Jonsson, H.; Reddy, G.V. Plant stem cell maintenance involves direct transcriptional repression of differentiation program. Mol. Syst. Biol. 2013, 9, 654. [CrossRef] [PubMed]

23. Daum, G.; Medzihradszky, A.; Suzaki, T.; Lohmann, J.U. A mechanistic framework for noncell autonomous stem cell induction in Arabidopsis. Proc. Natl. Acad. Sci. USA 2014, 111, 14619-14624. [CrossRef] [PubMed]

24. Perales, M.; Rodriguez, K.; Snipes, S.; Yadav, R.K.; Diaz-Mendoza, M.; Reddy, G.V. Threshold-dependent transcriptional discrimination underlies stem cell homeostasis. Proc. Natl. Acad. Sci. USA 2016, 113, E6298-E6306. [CrossRef] [PubMed] 
25. Yadav, R.K.; Perales, M.; Gruel, J.; Girke, T.; Jonsson, H.; Reddy, G.V. WUSCHEL protein movement mediates stem cell homeostasis in the Arabidopsis shoot apex. Genes Dev. 2011, 25, 2025-2030. [CrossRef] [PubMed]

26. Zhou, Y.; Liu, X.; Engstrom, E.M.; Nimchuk, Z.L.; Pruneda-Paz, J.L.; Tarr, P.T.; Yan, A.; Kay, S.A.; Meyerowitz, E.M. Control of plant stem cell function by conserved interacting transcriptional regulators. Nature 2015, 517, 377-380. [CrossRef] [PubMed]

27. Zhou, Y.; Yan, A.; Han, H.; Li, T.; Geng, Y.; Liu, X.; Meyerowitz, E.M. HAIRY MERISTEM with WUSCHEL confines CLAVATA3 expression to the outer apical meristem layers. Science 2018, 361, 502-506. [CrossRef] [PubMed]

28. Clark, S.E.; Running, M.P.; Meyerowitz, E.M. CLAVATA3 is a specific regulator of shoot and floral meristem development affecting the same processes as CLAVATA1. Development 1995, 121, 2057-2067.

29. Cock, J.M.; McCormick, S. A large family of genes that share homology with CLAVATA3. Plant Physiol. 2001, 126, 939-942. [CrossRef] [PubMed]

30. Goad, D.M.; Zhu, C.; Kellogg, E.A. Comprehensive identification and clustering of CLV3/ESR-related (CLE) genes in plants finds groups with potentially shared function. New Phytol. 2016, 16, 605-616. [CrossRef] [PubMed]

31. Whitewoods, C.D.; Cammarata, J.; Venza, Z.N.; Sang, S.; Crook, A.D.; Aoyama, T.; Wang, X.Y.; Waller, M.; Kamisugi, Y.; Cuming, A.C.; et al. CLAVATA was a genetic novelty for the morphological innovation of 3D growth in land plants. Curr. Biol. 2018, 28, 2365-2376. [CrossRef] [PubMed]

32. Fletcher, J.C.; Brand, U.; Running, M.P.; Simon, R.; Meyerowitz, E.M. Signaling of cell fate decisions by CLAVATA3 in Arabidopsis shoot meristems. Science 1999, 283, 1911-1914. [CrossRef] [PubMed]

33. Kondo, T.; Sawa, S.; Kinoshita, A.; Mizuno, S.; Kakimoto, T.; Fukuda, H.; Sakagami, Y. A plant peptide encoded by CLV3 identified by in situ MALDI-TOF MS analysis. Science 2006, 313, 845-848. [CrossRef] [PubMed]

34. Ohyama, K.; Shinohara, H.; Ogawa-Ohnishi, M.; Matsubayashi, Y. A glycopeptide regulating stem cell fate in Arabidopsis thaliana. Nat. Chem. Biol. 2009, 5, 578-580. [CrossRef] [PubMed]

35. Rojo, E.; Sharma, V.K.; Kovaleva, V.; Raikhel, N.V.; Fletcher, J.C. CLV3 is localized to the extracellular space, where it activates the Arabidopsis CLAVATA stem cell signaling pathway. Plant Cell 2002, 14, 969-977. [CrossRef] [PubMed]

36. Clark, S.E.; Williams, R.W.; Meyerowitz, E.M. The CLAVATA1 gene encodes a putative receptor kinase that controls shoot and floral meristem size in Arabidopsis. Cell 1997, 89, 575-585. [CrossRef]

37. Ogawa, M.; Shinohara, H.; Sakagami, Y.; Matsubayashi, Y. Arabidopsis CLV3 peptide directly binds the CLV1 ectodomain. Science 2008, 319, 294. [CrossRef] [PubMed]

38. Jeong, S.; Trotochaud, A.E.; Clark, S.E. The Arabidopsis CLAVATA2 gene encodes a receptor-like protein required for the stability of the CLAVATA1 receptor-like kinase. Plant Cell 1999, 11, 1925-1933. [CrossRef] [PubMed]

39. Muller, R.; Bleckmann, A.; Simon, R. The receptor kinase CORYNE of Arabidopsis transmits the stem cell-limiting signal CLAVATA3 independently of CLAVATA1. Plant Cell 2008, 20, 934-946. [CrossRef] [PubMed]

40. Nimchuk, Z.L.; Tarr, P.T.; Meyerowitz, E.M. An evolutionarily conserved pseudokinase mediates stem cell production in plants. Plant Cell 2011, 23, 851-854. [CrossRef] [PubMed]

41. Bleckmann, A.; Weidtkamp-Peters, S.; Seidel, C.A.M.; Simon, R. Stem cell signaling in Arabidopsis requires CRN to localize CLV2 to the plasma membrane. Plant Physiol. 2010, 152, 166-176. [CrossRef] [PubMed]

42. Guo, Y.; Han, L.; Hymes, M.; Denver, R.; Clark, S.E. CLAVATA2 forms a distinct CLE-binding receptor complex regulating Arabidopsis stem cell specification. Plant J. 2010, 63, 889-900. [CrossRef] [PubMed]

43. Zhu, Y.; Wang, Y.; Li, R.; Song, X.; Wang, Q.; Huang, S.; Jin, J.; Liu, C.; Lin, J. Analysis of interactions among the CLAVATA3 receptors reveals a direct interaction between CLAVATA2 and CORNYE in Arabidopsis. Plant J. 2010, 61, 223-233. [CrossRef] [PubMed]

44. Shinohara, H.; Matsubayashi, Y. Reevaluation of the CLV3-receptor interaction in the shoot apical meristem: Dissection of the CLV3 signaling pathway from a direct ligand-binding point of view. Plant J. 2015, 82, 328-336. [CrossRef] [PubMed]

45. DeYoung, B.; Bickle, K.L.; Schrage, K.J.; Muskett, P.; Patel, K.; Clark, S.E. The CLAVATA1-related BAM1, BAM2 and BAM3 receptor kinase-like proteins are required for meristem function in Arabidopsis. Plant J. 2006, 45, 1-16. [CrossRef] [PubMed] 
46. Kinoshita, A.; Betsuyaku, S.; Osakabe, Y.; Mizuno, S.; Nagawa, S.; Stahl, Y.; Simon, R.; Yamaguchi-Shinozaki, K.; Fukuda, H.; Sawa, S. RPK2 is an essential receptor-like kinase that transmits the CLV3 signal in Arabidopsis. Development 2010, 137, 3911-3920. [CrossRef] [PubMed]

47. Hu, C.; Zhu, Y.; Cui, Y.; Cheng, K.; Liang, W.; Wei, Z.; Zhu, M.; Yin, H.; Zeng, L.; Xiao, Y.; et al. A group of receptor kinases are essential for CLAVATA signalling to maintain stem cell homeostasis. Nat. Plants 2018, 4, 205-211. [CrossRef] [PubMed]

48. Brand, U.; Fletcher, J.C.; Hobe, M.; Meyerowitz, E.M.; Simon, R. Dependence of stem cell fate in Arabidopsis on a feedback loop regulated by CLV3 activity. Science 2000, 289, 617-619. [CrossRef] [PubMed]

49. Schoof, H.; Lenhard, M.; Haecker, A.; Mayer, K.F.X.; Jurgens, G.; Laux, T. The stem cell population of Arabidopsis shoot meristems is maintained by a regulatory loop between the CLAVATA and WUSCHEL genes. Cell 2000, 100, 635-644. [CrossRef]

50. Yang, Y.; Zhu, K.; Li, H.; Han, S.; Meng, Q.; Khan, S.U.; Fan, C.; Xie, K.; Zhou, Y. Precise editing of CLAVATA genes in Brassica napus L. regulates multilocular silique development. Plant Biotechnol. J. 2017, 16, 1322-1335. [CrossRef] [PubMed]

51. Zhang, L.W.; Li, S.P.; Chen, L.; Yang, G.S. Identification and mapping of a major dominant quantitative trait locus controlling seeds per silique as a single mendelian factor in Brassica napus L. Theor. Appl. Genet. 2012, 125, 695-705. [CrossRef] [PubMed]

52. Xu, P.; Cao, S.; Hu, K.; Wang, X.; Huang, W.; Wang, G.; Lv, Z.; Liu, Z.; Wen, J.; Yi, B.; et al. Trilocular phenotype in Brassica juncea L. resulted from interruption of CLAVATA1 gene homologue (BjMc1) transcription. Sci. Rep. 2017, 7, 3498. [CrossRef] [PubMed]

53. Lui, H. Brassica napus Genetics and Breeding; China Agricultural University Press: Beijing, China, 2000.

54. Fan, C.; Wu, Y.; Yang, Q.; Meng, Q.; Zhang, K.; Li, J.; Wang, J.; Zhou, Y. A novel single-nucleotide mutation in a CLAVATA3 gene homolog controls a multilocular silique trait in Brassica rapa L. Mol. Plant 2014, 7, 1788-1792. [CrossRef] [PubMed]

55. Zhao, H.C.; Du, D.Z.; Lui, Q.Y.; Yu, Q.L.; Wang, R.S. Study on multilocular heredity of B. juncea. J. Northwest Si-Tech Univ. Agric. For. (Nat. Sci. Ed.) 2003, 31, 90-92.

56. Xiao, L.; Li, X.; Liu, F.; Zhao, Z.; Xu, L.; Chen, C.; Wang, Y.; Shang, G.; Du, D. Mutations in the CDS and promoter of BjuA07.CLV1 cause a multilocular trait in Brassica juncea. Sci. Rep. 2018, 8, 5339. [CrossRef] [PubMed]

57. Lv, Z.W.; Xu, P.; Zhang, X.; Wen, J.; Yi, B.; Ma, C.; Tu, J.; Fu, T.; Shen, J. Primary study on anatomic and genetic analyses of multi-loculus in Brassica juncea. Chin. J. Oil Crop Sci. 2012, 34, 461-466.

58. Suzaki, T.; Toriba, T.; Fujimoto, M.; Tsutsumi, Y.; Kitano, H.; Hirano, H. Conservation and diversification of meristem mechanism in Oryza sativa: Function of the FLORAL ORGAN NUMBER2 gene. Plant Cell Physiol. 2006, 47, 1591-1602. [CrossRef] [PubMed]

59. Xu, C.; Liberatore, K.L.; MacAlister, C.A.; Huang, Z.; Chu, Y.-H.; Jiang, K.; Brooks, C.; Ogawa-Ohnishi, M.; Xiong, G.; Pauly, M.; et al. A cascade of arabinosyltransferases controls shoot meristem size in tomaro. Nat. Genet. 2015, 47, 784-792. [CrossRef] [PubMed]

60. Chu, H.; Qian, Q.; Liang, W.; Yin, C.; Tan, H.; Yao, X.; Yuan, Z.; Yang, J.; Huang, H.; Luo, D.; et al. The FLORAL ORGAN NUMBER4 gene encoding a putative ortholog of Arabidopsis CLAVATA3 regulates apical meristem size in rice. Plant Physiol. 2006, 142, 1039-1052. [CrossRef] [PubMed]

61. Je, B.I.; Xu, F.; Wu, Q.; Liu, L.; Meeley, R.; Gallagher, J.P.; Corcilius, L.; Payne, R.J.; Bartlett, M.E.; Jackson, D. The CLAVATA receptor FASCIATED EAR2 responds to distinct CLE peptides by signaling through two downstream effectors. eLife 2018, 7, e35673. [CrossRef] [PubMed]

62. Suzaki, T.; Sato, M.; Ashikari, M.; Miyoshi, M.; Nagato, Y.; Hirano, H.-Y. The gene FLORAL ORGAN NUMBER1 regulates floral meristem size in rice and encodes a leucine-rich repeat receptor kinase orthologous to Arabidopsis CLAVATA1. Development 2004, 131, 5649-5657. [CrossRef] [PubMed]

63. Bommert, P.; Lunde, C.; Nardmann, J.; Vollbrecht, E.; Running, M.P.; Jackson, D.; Hake, S.; Werr, W. Thick tassel dwarf1 encodes a putative maize ortholog of the Arabidopsis CLAVATA1 leucine-rich repeat receptor-like kinase. Development 2005, 132, 1235-1245. [CrossRef] [PubMed]

64. Tanksley, S.D. The genetic, developmental, and molecular bases of fruit size and shape variation in tomato. Plant Cell 2004, 16, S181-S189. [CrossRef] [PubMed] 
65. Lippman, Z.; Tanksley, S.D. Dissecting the genetic pathway to extreme fruit size in tomato using a cross between the small-fruited wild species L. pimpinellifolium and L. esculentum var. Giant Heirloom. Genetics 2001, 158, 413-422. [PubMed]

66. Munos, S.; Ranc, N.; Botton, E.; Berard, A.; Rolland, S.; Duffe, P.; Carretero, Y.; Le Paslier, M.-C.; Delalande, C.; Bouzayen, M.; et al. Increase in tomato locule number is controlled by two single-nucleotide polymorphisms located near WUSCHEL. Plant Physiol. 2011, 156, 2244-2254. [CrossRef] [PubMed]

67. Rodriguez-Leal, D.; Lemmon, Z.H.; Man, J.; Bartlett, M.; Lippman, Z. Engineering quantitative trait variation for crop improvement by genome editing. Cell 2017, 171, 470-480. [CrossRef] [PubMed]

68. Ogawa-Ohnishi, M.; Matsushita, W.; Matsubayashi, Y. Identification of three hydroxyproline o-arabinosyltransferases in Arabidopsis. Nat. Chem. Biol. 2013, 9, 726-730. [CrossRef] [PubMed]

69. Shinohara, H.; Matsubayashi, Y. Chemical synthesis of Arabidopsis CLV3 glycopeptide reveals the impact of hydroxyproline arabinosylation on peptide confirmation and activity. Plant Cell Physiol. 2013, 54, 369-374. [CrossRef] [PubMed]

70. Nagasawa, N.; Miyoshi, M.; Kitano, H.; Satoh, H.; Nagato, Y. Mutations associated with floral organ number in rice. Planta 1996, 198, 627-633. [CrossRef] [PubMed]

71. Suzaki, T.; Ohneda, M.; Toriba, T.; Yoshida, A.; Hirano, H. FON2 SPARE1 redundantly regulates floral meristem maintenance with FLORAL ORGAN NUMBER2 in rice. PLoS Genet. 2009, 5, e1000693. [CrossRef] [PubMed]

72. Suzaki, T.; Yoshida, A.; Hirano, H.Y. Functional diversification of CLAVATA3-related CLE proteins in meristem maintenance in rice. Plant Cell 2008, 20, 2049-2058. [CrossRef] [PubMed]

73. Ohmori, Y.; Tanaka, W.; Kojima, M.; Sakakibara, H.; Hirano, H. WUSCHEL-RELATED HOMEOBOX4 is involved in meristem maintenance and is negatively regulated by the CLE gene FCP1 in rice. Plant Cell 2013, 25, 229-241. [CrossRef] [PubMed]

74. Nardmann, J.; Werr, W. The shoot stem cell niche in angiosperms: Expression patterns of WUS orthologues in rice and maize imply major modifications in the course of mono- and dicot evolution. Mol. Biol. Evol. 2006, 23, 2492-2504. [CrossRef] [PubMed]

75. Tanaka, W.; Ohmori, Y.; Ushijima, T.; Matsusaka, H.; Matsushita, T.; Kumamaru, T.; Kawano, S.; Hirano, H. Axillary meristem formation in rice requires the WUSCHEL ortholog TILLERS ABSENT1. Plant Cell 2013, 27, 1173-1184. [CrossRef] [PubMed]

76. Doebley, J. The genetics of maize evolution. Annu. Rev. Genet. 2004, 38, 37-59. [CrossRef] [PubMed]

77. Jackson, D.; Hake, S. The genetics of ear fasciation in maize. Maize Genet. Coop. Newsl. 1999, 73, 2.

78. Bommert, P.; Nagasawa, N.S.; Jackson, D. Quantitative variation in maize kernel row number is controlled by the FASCIATED EAR2 locus. Nat. Genet. 2013, 45, 334-337. [CrossRef] [PubMed]

79. Bommert, P.; Je, B.I.; Goldschmidt, A.; Jackson, D. The maize G $\alpha$ gene COMPACT PLANT2 functions in CLAVATA signaling to control shoot meristem size. Nature 2013, 502, 555-558. [CrossRef] [PubMed]

80. Wu, Q.; Regan, M.; Furukawa, H.; Jackson, D. Role of heterotrimeric G $\alpha$ proteins in maize development and enhancement of agronomic traits. PLoS Genet. 2018, 14, e1007374. [CrossRef] [PubMed]

81. Je, B.I.; Gruel, J.; Lee, Y.K.; Bommert, P.; Arevalo, E.D.; Eveland, A.L.; Wu, Q.; Goldschmidt, A.; Meeley, R.; Bartlett, M.; et al. Signaling from maize organ primordia via FASCIATED EAR3 regulates stem cell proliferation and yield traits. Nat. Genet. 2016, 48, 785-791. [CrossRef] [PubMed]

82. Liu, L.; Du, Y.; Huo, D.; Wang, M.; Shen, X.; Yue, B.; Qiu, F.; Zheng, Y.; Yan, J.; Zhang, Z. Genetic architecture of maize kernel row number and whole genome prediction. Theor. Appl. Genet. 2015, 128, 2243-2254. [CrossRef] [PubMed]

83. Nardmann, J.; Werr, W. The invention of WUS-like stem cell-promoting functions in plants predates leptosporangiate ferns. Plant Mol. Biol. 2012, 78, 123-134. [CrossRef] [PubMed]

84. International Wheat Genome Sequencing Consortium. Shifting the limits in wheat research and breeding using a fully annotated reference genome. Science 2018, 361, eaar7191. [CrossRef] [PubMed]

85. Ma, X.; Zhang, Q.; Zhu, Q.; Liu, W.; Chen, Y.; Qiu, R.; Wang, B.; Yang, Z.; Li, H.; Lin, Y.; et al. A robust CRISPR/Cas9 system for convenient, high-efficiency multiplex genome editing in monocot and dicot plants. Mol. Plant 2015, 8, 1274-1284. [CrossRef] [PubMed]

(C) 2018 by the author. Licensee MDPI, Basel, Switzerland. This article is an open access article distributed under the terms and conditions of the Creative Commons Attribution (CC BY) license (http://creativecommons.org/licenses/by/4.0/). 